\title{
Foveolar-Type Adenoma
}

National Cancer Institute

\section{Source}

National Cancer Institute. Foveolar-Type Adenoma. NCI Thesaurus. Code C95779.

A rare neoplastic polyp that arises from the stomach. It is characterized by the presence

of foveolar-type epithelium. It may be seen in patients with familial adenomatous polyposis. 